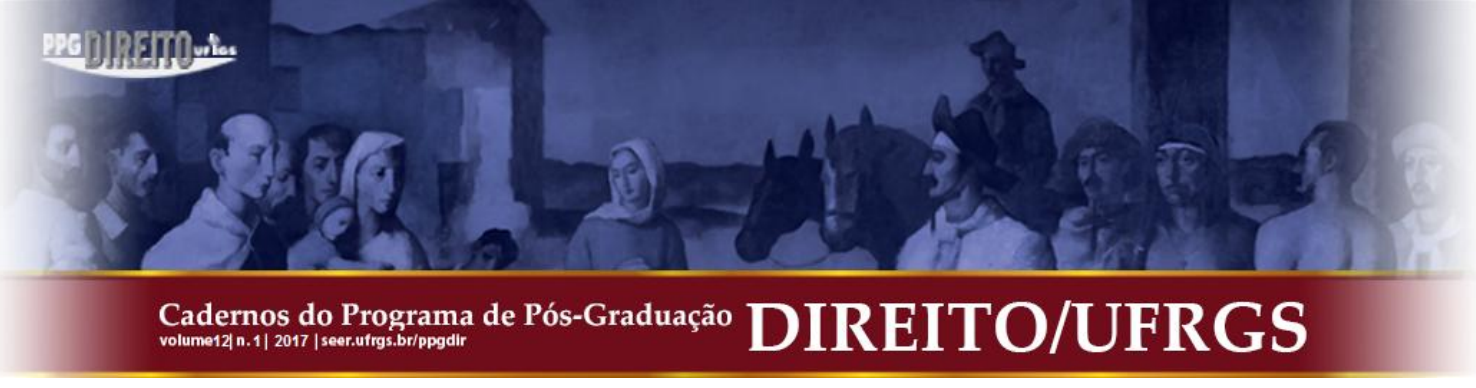

\title{
A JURISDIÇÃO CONSTITUCIONAL BRASILEIRA - APRESENTADA NO EXEMPLO DO CONTROLE DE NORMAS*
}

\author{
BRAZILIAN CONSTITUTIONAL ADJUDICATION - \\ PRESENTED IN THE EXAMPLE OF JUDICIAL REVIEW
}

Luís Afonso Heck ${ }^{* *}$

\begin{abstract}
RESUMO: O artigo procura apresentar a estrutura da jurisdição constitucional com base no controle de normas. Para isso, expõe comparativamente aspectos da estrutura do controle normativo brasileiro e alemão, a cada vez, com observações. Segue-se a essa exposição, na consideração final, uma proposta de lege ferenda para o controle normativo brasileiro atual.
\end{abstract}

PALAVRAS-CHAVE: Jurisdição Constitucional. Controle de Normas. Direito Comparado.
ABSTRACT: The article endeavors to present the structure of constitutional adjudication with a basis on judicial review. For that end, it expounds comparatively aspects of the structure of Brazilian and German judicial review, in each case, with observations. Following this exposition, in a final consideration, is a de lege ferenda proposal for the current Brazilian judicial review.

SUMÁRIO: Nota Prévia. 1 O Supremo Tribunal Federal. 1.1 Número, Eleição e Nomeação dos Juízes no Supremo Tribunal Federal. 1.2 Competência. 2 Controle de Normas. 2.1 Controle de Normas Concentrado. 2.1.1 Objeto. 2.1.2 Algumas Questões. 2.1.3 Autorizados à Propositura. 2.1.4 Monopólio do Exame e da Rejeição de Normas. 2.1.5 Aspectos da Comparação de Direito. 2.2 Controle de Normas Difuso. 3.2.1 Autorizados à Propositura. 3.2.2 Monopólio do Exame e da Rejeição de Normas. 2.2.3 Aspectos da Comparação de Direito. 3 Vinculação da Decisão. 3.1 No Controle de Normas Concentrado. 3.2 No controle de Normas Difuso. 4 Nulidade ou Nulificabilidade. Considerações Finais. Referências.

\section{NOTA PRÉVIA}

Em 5 de outubro de 1988 a Constituição Federal brasileira (CF) entrou em vigor. Segundo o texto da constituição, o Brasil é, assim como exprime a Lei Fundamental da Alemanha $(\mathrm{LF})^{1}$, uma república federal, artigo $1^{2}$. Ela compõe-se da união indissolúvel de estados, municípios e do Distrito Federal (Brasília). O Brasil é, como a Alemanhaª , um Estado de Direito Democrático, artigo $1^{0}$ da Constituição Federal ${ }^{4}$.

\footnotetext{
* Este texto se trata de uma formulação ampliada da exposição que o autor fez em dezembro de 2012 na Universidade de Konstanz (Alemanha). O autor agradece a Hartmut Maurer pelo convite, a Martin Ibler por indicações e aos alunos pelo estímulo das perguntas.

** Doutor em Direito pela Universidade Federal de Minas Gerais (UFMG). Professor do Programa de PósGraduação em Direito da Universidade Federal do Rio Grande do Sul (UFRGS).

${ }^{1}$ ALEMANHA. Lei Fundamental, de 08 de maio de 1949. Artigo 20 I.

2 BRASIL. Constituição da República Federal do Brasil, de 05 de outubro de 1988. Título: "Constituição da República Federal do Brasil". Artigo 1: “A República Federal brasileira (...)”.

${ }^{3}$ ALEMANHA. Lei Fundamental, de 08 de maio de 1949. Artigo 20 I.

${ }^{4}$ BRASIL. Constituição da República Federal do Brasil, de 05 de outubro de 1988. No artigo 1 está: “(...) Estado Democrático de Direito". A formulação não é feliz, pois um Estado de Direito pode ser democrático ou não e um Estado Democrático implica o Estado de Direito.
} 


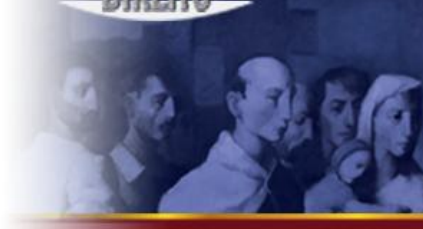

\section{Cadernos do Programa de Pós-Graduação
volume12|n.1| 2017| seer.utrgs.br/ppgdir}

Os estados no Brasil têm, como o Distrito Federal também, uma jurisdição própria, comparar artigo 92 VII, CF. Esse artigo também faz referência aos territórios. Atualmente eles não mais existem, pois os artigos 14, 15 (Ato das Disposições Constitucionais Transitórias) cortaram eles. Eles podem, porém, por estrutura nova territorial, novamente ser reestabelecidos, artigo 12, CF (Ato das Disposições Constitucionais Transitórias).

Aqui deve ser perseguida a estrutura da jurisdição constitucional no exemplo do controle de normas. Para isso, será, em primeiro lugar, apresentado o Supremo Tribunal Federal. Depois, será exposto o controle de normas com uma visão de conjunto da comparação de direito. E, por fim, seguem algumas observações com uma proposta para a formação futura do controle de normas no Brasil.

\section{O SUPREMO TRIBUNAL FEDERAL}

O Supremo Tribunal Federal está na ponta da estrutura judicial-constitucional. Ele deve, com apoio na classificação do controle de normas por Maurer, ser posto sob o controle de normas integrado ${ }^{5}$. Os juízes do Supremo Tribunal Federal não precisam ser juízes profissionais. Eles também não são eleitos pelo Congresso Nacional, mas pelo Presidente Federal, embora o início da proposição do parágrafo único do artigo $1, \mathrm{CF}$, diga a mesma coisa como a primeira proposição do artigo 20 II, da LF: "Todo o poder estatal provém do povo." Para o Supremo Tribunal Federal também não vale a "regra-quinto"6.

A ele cabe hoje, sem dúvida, um papel importante na vida constitucional brasileira, mas esse papel e, mais além, sua consideração dependem da fundamentação de suas decisões, assim como da força de convencimento de seus argumentos. Aqui se mostra não só a importância fundamental de formação e pré-compreensão no sentido gadameriano ${ }^{7}$, mas

\footnotetext{
${ }^{5}$ MAURER, Hartmut. Jurisdição constitucional. In: MAURER, Hartmut. Contributos para o direito do estado. Tradução de Luís Afonso Heck. Porto Alegre: Livraria do Advogado, 2007, p. 246, número de margem 73.

${ }^{6}$ A chamada "regra-quinto" indica que 1/5 dos lugares dos tribunais regionais federais, dos tribunais de justiça dos estados, do Distrito Federal e dos territórios serão ocupados por membros do Ministério Público e advogados (BRASIL. Constituição da República Federal do Brasil, de 05 de outubro de 1988. Artigo 94). Tenta-se, com isso, deixar-se fazer valer, sobretudo, a experiência nesses âmbitos no tribunal. Isso deve, assim, contribuir para uma visão melhor e mais completa e para a compreensão do conflito jurídico. Isso tem, então também, seu efeito na sentença do tribunal.

${ }^{7}$ Para isso, GADAMER, Hans-Georg. Wahrheit und Methode 1. Grundzüge einer philosophischen Hermeneutik. 6. Auflage. Tübingen: Mohr, 1990, S. 15 ff., 270 ff. Naturalmente, a questão da formação vale não somente para os juízes, mas para todos os juristas, melhor ainda, para todos os cidadãos. Aqui pode ficar em aberto até que ponto o fato, que no Brasil a maioria dos professores de direito são advogados, isto é, são ativos em um escritório, repercute no conhecimento do direito e, assim, na jurisprudência dos tribunais. Deixa-se, contudo, 


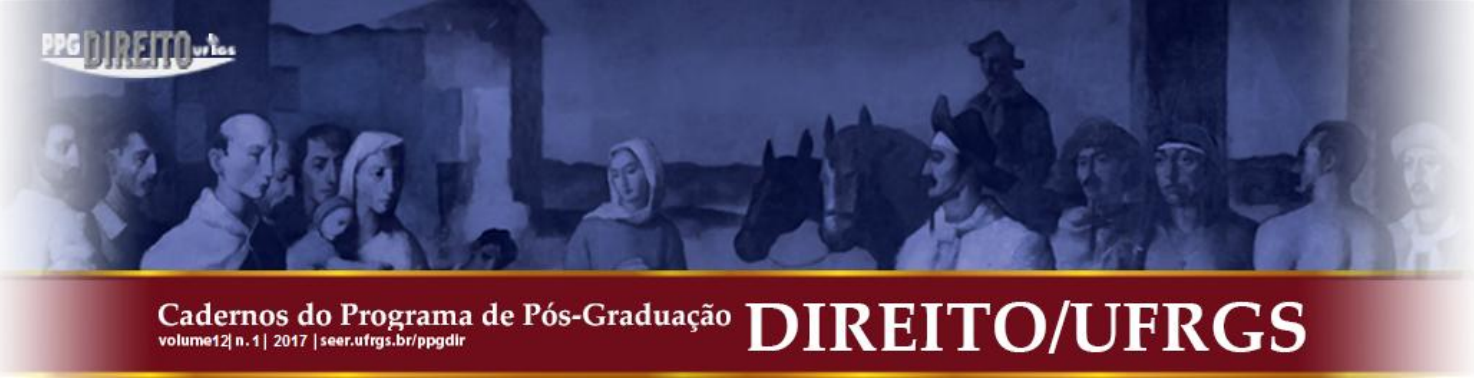

também a conexão interna entre elas. Uma formação que visa à pré-compreensão da estrutura de uma ordem jurídica representa o adestramento que, outra vez, é pressuposto para uma fundamentação juridicamente correta. Não somente uma compensação entre teoria e prática, mas também uma união real entre doutrina e investigação nas faculdades de direito seria oportuna.

No seguinte devem ser apresentadas (comparando direito) a configuração e competência do Supremo Tribunal Federal.

\subsection{Número, Eleição e Nomeação dos Juízes no Supremo Tribunal Federal}

A Constituição Federal determina não somente o número dos juízes para o Supremo Tribunal Federal, mas também a eleição ${ }^{8}$ e a nomeação. Ele é ocupado por onze juízes (denominados ministros). Eles são escolhidos dentre os cidadãos, têm de ter mais de 35 e menos de 65 anos de idade, ter um saber jurídico amplo e uma reputação excelente (artigo 101, CF). Eles são nomeados pelo Presidente Federal depois da aprovação da seleção pelo Senado Federal. A aprovação requer a maioria absoluta (artigo 101, CF). A aprovação pelo Senado Federal realiza-se por votação secreta. Um interrogatório público precede à aprovação (artigo 52 III a, CF). O interrogatório é comparável com o procedimento usual nos Estados Unidos para a nomeação dos juízes na Suprema Corte.

\subsection{Competência}

As competências do Supremo Tribunal Federal estão determinadas no artigo 102, CF. Segundo o artigo 102, CF, cabe ao Supremo Tribunal Federal fundamentalmente a guarda ou salvaguarda da Constituição. Nesse sentido, devem, no que segue, interessar somente as competências com vista ao controle de normas.

\section{CONTROLE DE NORMAS}

Deixam distinguir-se dois tipos de controle de normas no direito constitucional brasileiro. O concentrado e o difuso. A Constituição Federal de 1988 dilatou a configuração

dizer uma coisa: com isso, trata-se, em grande parte, não de um saber cultivado institucionalmente, mas antes, de um saber individual, prático.

${ }^{8}$ A competência para essa eleição não é legalmente determinada. 


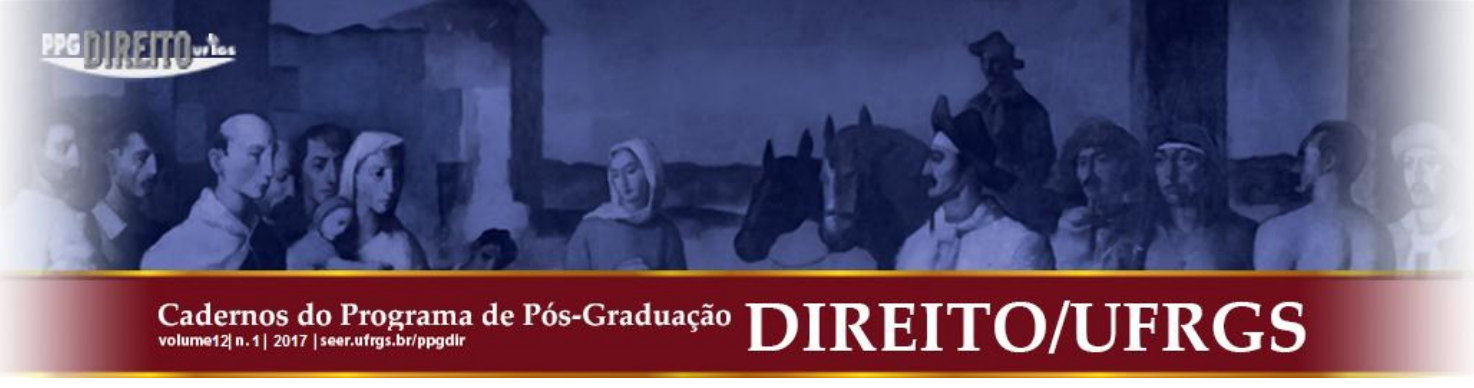

do controle de normas concentrado e, precisamente, relacionado ao número dos autorizados à propositura e ao da promoção.

Ao lado do controle de normas concentrado pode colocar-se o abstrato e o principal. E ao lado do controle de normas difuso deixam fixar-se o concreto e o incidental. Eles deixam, portanto, combinar-se ${ }^{9}$. Ambos os controles de normas, concentrado e difuso, devem, contudo, ser delimitados dos outros pela característica da competência, isto é, no controle de normas concentrado um tribunal tem o poder para o exame e rejeição da norma jurídica a ser controlada e no controle de normas difuso esse poder é confiado ao juiz. ${ }^{10}$ As exposições seguintes devem, com isso, comprovar que o emprego desse par conceitual está justificado, pois ele mostra-se mais idôneo não só para apresentar a estrutura do controle de normas brasileiro, mas também para tratar objetivamente as questões principais do controle de normas brasileiro atual.

\subsection{Controle de Normas Concentrado}

Ele está, por um lado, normalizado no artigo 102 I a, CF. Esse descansa sobre a Lei de Modificação da Constituição número 3, de 17 de março de 1993. A esse seguiu a Lei número 9.868 , de 10 de novembro de 1999 , que regula o controle de normas concentrado ${ }^{11}$. Outras

\footnotetext{
${ }^{9}$ Ver para isso, MAURER, Hartmut. op. cit., p. 246, número de margem 74.

${ }^{10}$ Aqui é importante acentuar duas questões. A primeira diz respeito aos passos que compõem a competência do exame e a da rejeição. Eles podem ser assim apresentados:

passo 1: existência de dúvida;

passo 2: eliminação da dúvida pela autoridade competente;

passo 3: confronto entre a norma inferior e superior;

passo 4: comprovação da compatibilidade ou incompatibilidade entre elas;

passo 5: declaração de constitucionalidade ou inconstitucionalidade. Os passos 1-4 compreendem a competência para o exame. O passo 5 , a competência para a rejeição.

A segunda refere-se à terminologia. Para o sistema concentrado é remetido à Áustria, porque ambas essas competências estão situadas em uma única instância, no tribunal constitucional. Para o sistema difuso é indicado os Estados Unidos da América, porque essas competências estão nas mãos de juízes de instâncias diferentes.

${ }^{11}$ De outra forma como na Alemanha, onde existe uma lei sobre o Tribunal Constitucional Federal, não existe no Brasil uma lei sobre o Supremo Tribunal Federal. Existe somente o regimento interno do Supremo Tribunal Federal. Isso é um defeito, pois o regimento interno é, de outra forma como uma lei sobre o tribunal, que foi criada pelo dador de leis, determinado pelo tribunal mesmo. Disso resulta o perigo que o tribunal pode dar-se mais poderes que a Constituição compete dar. A história da súmula vinculante e do efeito transcendental da decisão do Supremo Tribunal Federal, em virtude do artigo 97, da Constituição Federal, é um exemplo para isso. A súmula vinculante baseia-se em decisões repetidas sobre assuntos da Constituição. Ela compõe-se de uma proposição, que é formulada disso. Ela tem efeito vinculante para todos os outros órgãos do poder judicial e para a administração pública no plano federal, estadual e municipal (BRASIL. Constituição da República Federal do Brasil, de 05 de outubro de 1988. Artigo 103-A, introduzida pela Lei de Modificação da Constituição número 45, de 8 de dezembro de 2004). Ela deve servir à reconciliação dos juízes e à "pacificação" da jurisprudência.
} 


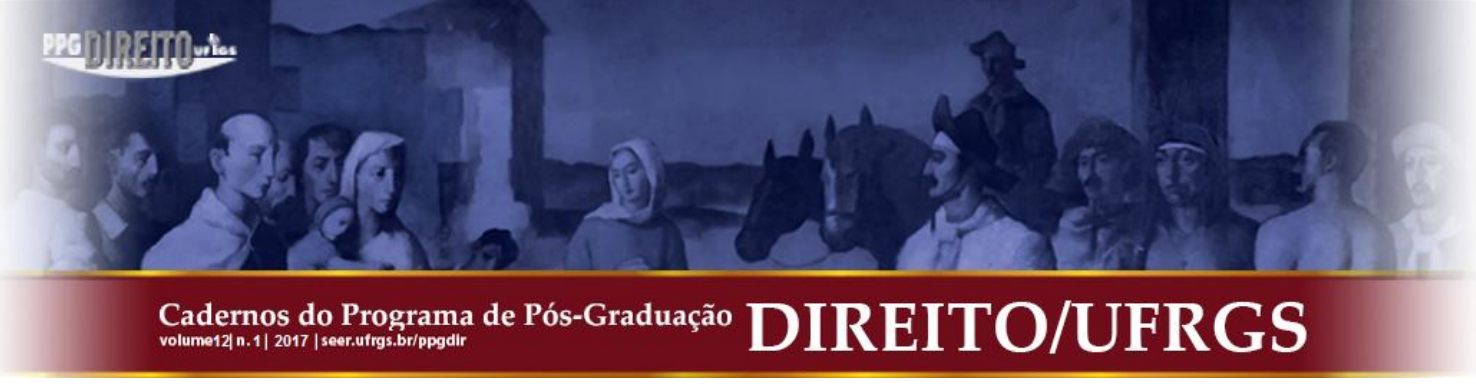

regulações contém o artigo $102 \S 1, \mathrm{CF}$, que também foi introduzido pela Lei de Modificação da Constituição número 3, de 17 de março de 1993. A esse seguiu a Lei número 9.882, de 3 de dezembro de 1999, que normalizou esse parágrafo. Ele está, por outro lado, fixado também no artigo $102 \S 2, \mathrm{CF}$, que foi introduzido pela Lei de Modificação da Constituição número 45, de 8 de dezembro de 2004. Ademais, o artigo 103, CF, que foi modificado pela Lei de Modificação da Constituição número 45, de 8 de dezembro de 2004, contém regulações para o controle de normas concentrado.

O controle de normas concentrado pode no Supremo Tribunal Federal ser promovido: - pela ação direta de inconstitucionalidade de uma lei ou de um ato normativo federal ${ }^{12}$ ou ato normativo estadual (artigo 102 I a, CF);

- pela ação direta de constitucionalidade de uma lei ou de um ato normativo federal (artigo 102 I a, CF);

- pela afirmação do não-cumprimento de uma prescrição fundamental (artigo $102 \S 1$, CF);

- pela afirmação da omissão de uma medida que concede eficácia a uma norma constitucional (artigo $103 \S 2, \mathrm{CF})$;

-por representação do Procurador-Geral da República (a chamada representação interventiva) (artigo 36 III, CF).

\subsubsection{Objeto}

Objeto da ação direta de inconstitucionalidade podem ser: leis federais e atos normativos federais, leis estaduais e atos normativos estaduais, leis e atos normativos do distrito federal, regulamentos legislativos e decisões no plano federal, estadual e do Distrito Federal.

Objeto da ação direta de constitucionalidade podem ser: leis federais e atos normativos federais, regulamentos legislativos federais e decisões federais.

\footnotetext{
Ela foi introduzida sob a Constituição Federal de 1946 por modificação do regimento interno de então do supremo tribunal federal. Ela deveria servir à unificação da jurisprudência. Ela não era formalmente vinculativa, porém, deveria realmente, segundo o sentido, ser materialmente, pois ela não mais podia ser interpretada. $\mathrm{O}$ efeito transcendental deve, como efeito vinculativo, valer no controle de normas difuso. Transcendental quer dizer: vale também para todos os outros casos futuros; comparar BRASIL. Supremo Tribunal Federal. Recurso Extraordinário 197917 e BRASIL. Supremo Tribunal Federal. Habeas Corpus 82959.

${ }^{12}$ Sob ato normativo deve ser entendido cada prescrição jurídica que hierarquicamente está sob a lei.
} 


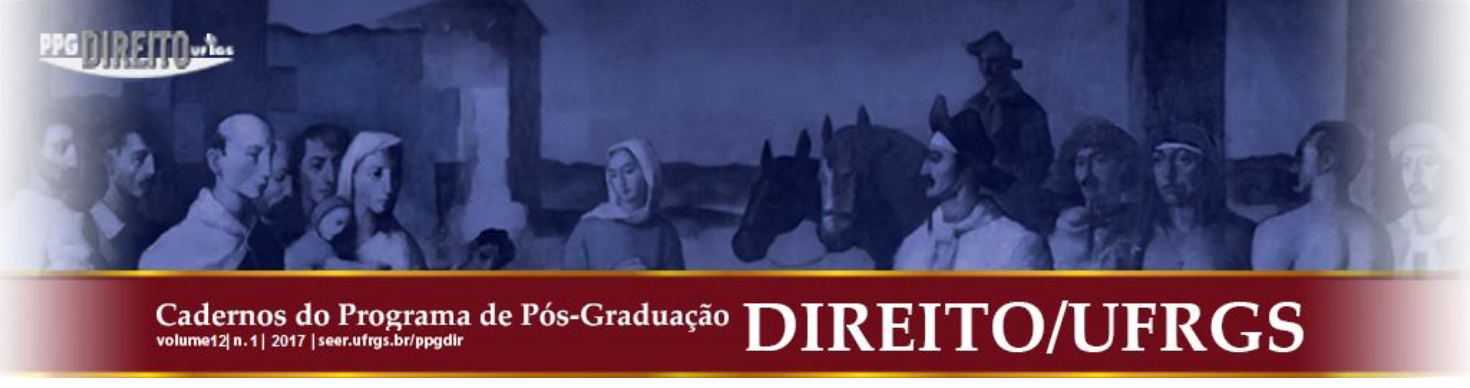

A afirmação do não-cumprimento de uma prescrição fundamental pode ter como objeto: atos do poder público, leis ou atos normativos da federação, dos estados ou dos municípios, antes e depois do direito constitucional federal.

A afirmação da omissão de uma medida, que concede eficácia a uma norma constitucional, pode ter como objeto uma omissão do dador de leis ou do executivo.

Objeto da representação do Procurador-Geral da República é o asseguramento da observância dos princípios constitucionais fixados no artigo 34 VII, CF.

\subsubsection{Algumas questões}

(a) A ação direta de constitucionalidade mostra juridicamente um problema difícil: ela viola o favor legis. É malogrado político-juridicamente quando o cidadão, pelo voto, dá ao Congresso Nacional a confiança e legitima ele, com isso, politicamente e, então, o resultado da atividade legislativa, isto é, a lei formal, abstratamente pode ser posto em dúvida por alguns autorizados à propositura nem sequer eleitos (Procurador-Geral da República, artigo 103 VI, CF, Conselho Federal da Ordem dos Advogados do Brasil, artigo 103 VII, CF, confederação sindical ou entidade de classe de âmbito nacional). Aqui o Supremo Tribunal Federal intervém muito amplamente no âmbito do dador de leis. Pois pela ação direta de constitucionalidade a realização da Constituição pelo dador de leis é apresentada como violação da Constituição. Pensa-se agora ainda no executivo, que também pela eleição dos cidadãos é politicamente legitimado e com o veto pode proteger a Constituição (artigo $84 \mathrm{~V}$, $\mathrm{CF}$ ) ao ele recusar com o veto o projeto de lei violador da Constituição, então a ação direta de constitucionalidade intervém também na função, jurídico-constitucionalmente determinada, do executivo. Mais além, a ação direta de constitucionalidade retira a competência do exame de normas do juiz particular no controle de normas difuso com aprovação duvidosa do Supremo Tribunal Federal ${ }^{13}$. Não por último, a ação direta de constitucionalidade impede a comprovação judicial do aspecto dinâmico da lacuna normativa mencionado pelo Tribunal Constitucional Federal ${ }^{14}$.

\footnotetext{
${ }^{13}$ BRASIL. Supremo Tribunal Federal. RTJ 220, p. 206.

${ }^{14}$ Ver para isso, HECK, Luís Afonso. O tribunal constitucional federal e o desenvolvimento dos princípios constitucionais. Contributo para uma compreensão da jurisdição constitucional federal alemã. 2. ed. Porto Alegre: Sergio Antonio Fabris, 2012, p 209.
} 


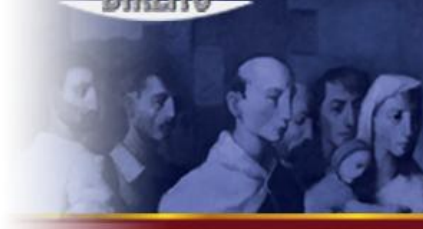

\section{Cadernos do Programa de Pós-Graduação
volume12|n.1| 2017| seer.utrgs.br/ppgdir}

Tudo isso poderia ser evitado por um controle de normas preventivo, pois a lei poderia então, antes de ela ser publicada, pelo Supremo Tribunal Federal ser revisada em sua constitucionalidade.

(b) O não-cumprimento de uma prescrição fundamental apresenta a questão, do que então se trata quando se fala de "prescrição fundamental". A jurisprudência do Supremo Tribunal Federal vacila. Na RTJ 199 (878) o tribunal é da opinião que "é muito difícil indicar a priori as prescrições fundamentais da constituição que são capazes de uma violação tão grave que ela fundamenta um procedimento e um juízo com a afirmação do nãocumprimento". Então, o tribunal, na página 880, designa a divisão de poderes, a forma federativa de Estado e os direitos e garantias fundamentais como prescrições fundamentais (com indicação bibliográfica). Na RTJ 206 (969 e seguintes) o tribunal entende a autonomia municipal como prescrição fundamental. E na RTJ 213 (21 e seguintes) a liberdade de imprensa, em união com os direitos e garantias fundamentais, designada como prescrição fundamental.

Na literatura também não se está de acordo sobre isso. Existe até uma certa confusão. Isso mostra, por exemplo, o livro "Arguição de descumprimento de preceito fundamental: análise à luz da Lei número 9.882/99”, que não só procede de vários autores, mas também trata tematicamente a prescrição fundamental ${ }^{15}$.

O cidadão, que é titular dos direitos fundamentais, não tem um acesso jurídicoconstitucional $^{16}$ ao Supremo Tribunal Federal para fazer valer em sentido amplo seus direitos

15 TAVARES, André Ramos; ROTHENBURG, Walter Claudius (Org.). Argüição de descumprimento de preceito fundamental: análises à luz da lei n. 9.882/99. São Paulo: Atlas, 2001. Assim, na página 17 (A. de Moraes. Direitos e garantias fundamentais da Constituição, fundamentos e objetivos fundamentais da república), página 49 e seguintes (A. R. Tavares. Valores constitucionais, preceitos como conjunto de princípios e regras), página 78 e seguintes (C. S. R. Bastos. Valores constitucionais básicos), página 91 e seguintes (D. Sarmento. Direitos fundamentais, cláusulas pétreas do artigo 60, § 4, CF, princípios fundamentais da república, artigo 1-5, $\mathrm{CF}$ ), página 128 e seguintes (G. F. Mendes Direitos e garantias individuais, artigo 5, CF, princípios protegidos pela cláusula pétrea, artigo 60, § 4, CF, princípios sensíveis do artigo 34, CF), página 211 e seguintes (W. C. Rothenburg. Fundamentos, artigo 1, CF, objetivos, artigo 3, CF, princípios retores das relações internacionais, artigo 4, CF).

${ }^{16}$ No Brasil não existe recurso constitucional. No artigo 5, da Constituição Federal, sob o título "Direitos e garantias fundamentais" estão previstos os seguintes expedientes jurídicos: habeas corpus (LXVIII), mandado de segurança (LXIX), mandado de injunção (LXXI) e habeas data (LXXII). O habeas corpus protege a liberdade de locomoção (BRASIL. Constituição da República Federal do Brasil, de 05 de outubro de 1988. Artigo 5 LXVIII e BRASIL. Código de Processo Penal. Decreto-Lei 3.689, de 3 de outubro de 1941. Artigo 647), o mandado de segurança, direitos que são indiscutíveis, isto é, a forma documental, como prova, tem de valer definitivamente (aqui pode ser mencionado o processo de documentos), e não protegidos por habeas corpus ou habeas data (BRASIL. Constituição da República Federal do Brasil, de 05 de outubro de 1988. Artigo 5 LXIX e BRASIL. Lei 12.016, de 7 de agosto de 2009. Artigo $1^{0}$ ). O mandado de injunção protege o exercício de direitos 
fundamentais perante a violação pelo poder público, isto é, poder legislativo, executivo e judicial. De outra forma sucede com o recurso constitucional alemão, que abarca o poder público em sentido amplo (§ 90 I, Lei sobre o Tribunal Constitucional Federal). A Lei número 9.882, de 3 de dezembro de 1999, deu, sem dúvida, no artigo 2 II para "cada pessoa violada ou ameaçada por atos do poder público" a autorização à demanda para a afirmação do nãocumprimento de uma prescrição fundamental. Mas não diretamente no Supremo Tribunal Federal, mas somente por representação pode a pessoa afetada apresentar a solicitação para a promoção da afirmação do não-cumprimento de uma prescrição fundamental ao ProcuradorGeral da República. Este decide então sobre a promoção da demanda (artigo $2 \S 1$, Lei número $9.882^{17}$ ). Contra o artigo 2 II, da Lei número 9.882, foi promovido um veto do executivo $^{18}$. Isso permite identificar a prescrição fundamental com direitos fundamentais e garantias de direitos fundamentais.

constitucionais e de liberdade e os privilégios que são inerentes à nacionalidade, soberania (popular) e direitos do cidadão, quando para isso falta a norma regularizadora (BRASIL. Constituição da República Federal do Brasil, de 05 de outubro de 1988. Artigo 5 LXXI) e o habeas data, o conhecimento e correção de bancos de dados públicos ou acessíveis publicamente (BRASIL. Constituição da República Federal do Brasil, de 05 de outubro de 1988. Artigo 5 LXXII, CF, e BRASIL. Lei 9.507, de 12 de novembro de 1997. Artigo 7 I-III).

O Supremo Tribunal Federal pode, com estes expedientes jurídicos, como primeira instância ser chamado:

a) com o habeas corpus: à medida que o afetado é o Presidente da República, o Vice-Presidente, um membro do Congresso Nacional, o Procurador-Geral da República, um ministro de Estado, um comandante das Forças Armadas, um membro de um tribunal superior, do Tribunal de Contas da União e o dirigente de uma representação no estrangeiro contínua da República do Brasil (BRASIL. Constituição da República Federal do Brasil, de 05 de outubro de 1988. Artigo 102 I d);

à medida que o prejudicador é um tribunal superior ou à medida que o prejudicador ou afetado é uma autoridade ou funcionário, cujos atos estão sujeitos à jurisdição do Supremo Tribunal Federal, ou se trata de um crime que está sujeito à jurisdição do Supremo Tribunal Federal como única instância (BRASIL. Constituição da República Federal do Brasil, de 05 de outubro de 1988. Artigo 102 I i);

b) com o mandado de segurança: contra atos do Presidente da República, da mesa da Câmara dos Deputados e do Senado Federal, do Tribunal de Contas da União, do Procurador-Geral da República e do Supremo Tribunal Federal (BRASIL. Constituição da República Federal do Brasil, de 05 de outubro de 1988. Artigo 102 I d);

c) com o mandado de injunção: à medida que a norma regularizadora cabe ao Presidente da República, ao Congresso Nacional, à Câmara dos Deputados, ao Senado Federal, à mesa da Câmara dos Deputados ou do Senado Federal, ao Tribunal de Contas da União, a um dos tribunais superiores ou ao Supremo Tribunal Federal (BRASIL. Constituição da República Federal do Brasil, de 05 de outubro de 1988. Artigo 102 I q);

d) com o habeas data: contra atos do Presidente da República, da mesa da Câmara dos Deputados e do Senado Federal, do Tribunal de Contas da União, do Procurador-Geral da República e do Supremo Tribunal Federal (BRASIL. Constituição da República Federal do Brasil, de 05 de outubro de 1988. Artigo 102 I d).

Ele pode, a seguir, também como tribunal de revisão de última instância ser chamado para as solicitações de habeas corpus, mandado de segurança, mandado de injunção e de habeas data recusadas (BRASIL. Constituição da República Federal do Brasil, de 05 de outubro de 1988. Artigo 102 II a).

17 A posição do Procurador-Geral da República assemelha-se ao advogado da Constituição de Kelsen. Ver KELSEN, Hans. Wesen und Entwicklung der Staatsgerichtsbarkeit. VVDStRL, n. 5, 1929, S. 75.

${ }^{18} \mathrm{O}$ veto apresenta os autorizados à propositura, que estão previstos no artigo 103 I-IX, da Constituição Federal, como representantes dos cidadãos. Primeiro, eles não são isso juridicamente, segundo, isso é uma ideia falsa, pois do Estado de Direito faz parte também a independência jurídico-procedimental do cidadão. Essa tutela soa a paternalismo.

Cadernos do Programa de Pós-Graduação em Direito PPGDir./UFRGS | Edição Digital | Porto Alegre | Volume XII | Número 1 | 2017 | P. 166 - 187 


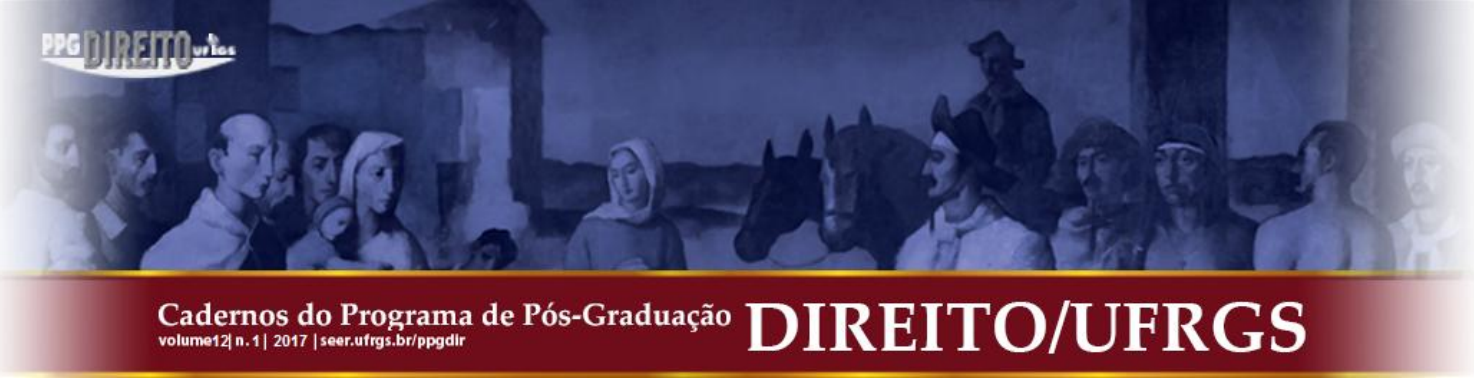

O artigo 4 1, da Lei número 9.882, indica ainda que a afirmação do nãocumprimento da prescrição fundamental não será admitida se existe um outro meio eficaz para a eliminação da violação. Isso assemelha-se à subsidiariedade do recurso constitucional, como ela foi desenvolvida pelo Tribunal Constitucional Federal alemão ${ }^{19}$.

\subsubsection{Autorizados à Propositura}

A ação direta de inconstitucionalidade, assim como a ação direta de constitucionalidade podem, segundo o artigo 103 alíneas I-IX, CF, artigo 2 alíneas I-IX, artigo 13 alíneas I-IX ${ }^{20}$, Lei número 9.868, de 10 de novembro de 1999, ser promovidas pelo

- Presidente da República (I)

- mesa do Senado Federal (II)

- mesa da Câmara dos Deputados (III)

- mesa de Assembleia Legislativa ou Câmara Legislativa do Distrito Federal (IV)

- Governador de estado ou do Distrito Federal (V)

- Procurador-Geral da República (VI)

- Conselho Federal da Ordem dos Advogados do Brasil (VII)

- partido político com representação no Congresso Nacional (VIII)

- confederação sindical ou entidade de classe ${ }^{21}$ de âmbito nacional (IX).

Os autorizados à propositura, determinados nas alíneas I-IX, CF, também podem apresentar uma solicitação com a afirmação do não-cumprimento de uma prescrição fundamental.

\footnotetext{
${ }^{19}$ Ver HECK, Luís Afonso. O recurso constitucional na sistemática jurídico-constitucional alemã. Revista de informação legislativa, Brasília, n. 124, out./dez., 1994, p. 124 et seq. Com o veto ao artigo 2 II, Lei número 9.882, de 3 de dezembro de 1999, o sentido dessa instância-subsidiariedade foi, contudo, perdido. Aquilo que depois do veto restou mostra-se como uma seleção da via jurídica. O Supremo Tribunal Federal fala, apesar disso, ainda de subsidiariedade. Considerado com isso é agora uma via jurídica-subsidiariedade para o Supremo Tribunal Federal. Comparar BRASIL. Supremo Tribunal Federal. RTJ 194, 2, p. 393; BRASIL. Supremo Tribunal Federal. RTJ 199, 3, p. 888 et seq.; BRASIL. Supremo Tribunal Federal. RTJ 207, 3, p. 1283; BRASIL. Supremo Tribunal Federal. RTJ 210, 3, p. 1049; BRASIL. Supremo Tribunal Federal. RTJ 211, p. 11; BRASIL. Supremo Tribunal Federal. RTJ 213, p.20; BRASIL. Supremo Tribunal Federal. RTJ 215, p. 31; BRASIL. Supremo Tribunal Federal. RTJ 216, p.52; BRASIL. Supremo Tribunal Federal. RTJ 218, p.11.

${ }^{20} \mathrm{O}$ artigo 13 , da Lei número 9.868 , de 10 de novembro de 1999 , previu originalmente somente os autorizados à propositura mencionados no artigo 103 I, II, III e VI, da Constituição Federal. A Lei de Modificação da Constituição número 45, de 8 de dezembro de 2004, equiparou a ação direta de inconstitucionalidade e a ação direta de constitucionalidade referente aos autorizados à propositura.

${ }^{21}$ Grêmios profissionais de profissões acadêmicas e técnicas.
} 


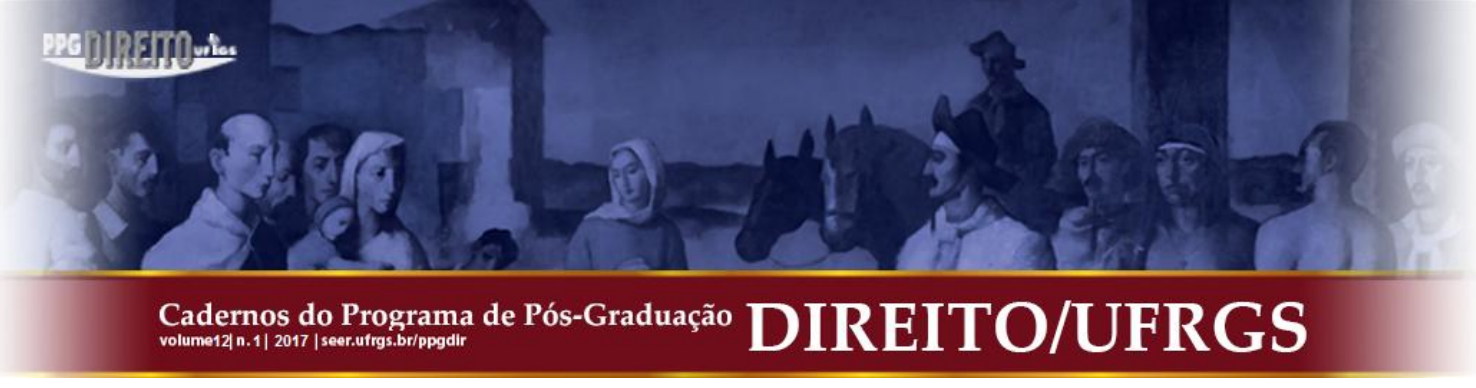

Além disso, na ação de inconstitucionalidade deve o Procurador-Geral da República ser ouvido previamente (artigo $103 \S 1, \mathrm{CF}$ ) e quando o Supremo Tribunal Federal aprecia em tese a inconstitucionalidade de uma norma legal ou de um ato normativo, então o AdvogadoGeral da União é citado para defender o texto ou ato impugnado (artigo 103 §, CF).

\subsubsection{Monopólio do Exame e da Rejeição de Normas}

No controle de normas concentrado o Supremo Tribunal Federal tem o monopólio do exame e da rejeição de normas (artigo 102 § 2, CF; artigo 1, da Lei número 9.868, de 10 de novembro de 1999).

\subsubsection{Aspectos da Comparação de Direito}

Perante o direito constitucional alemão pode comprovar-se o seguinte:

(a) a ação direta de inconstitucionalidade corresponde ao controle de normas abstrato (artigo 93 I número 2, LF, § 13 número 6, $§ 76$ e seguintes, Lei sobre o Tribunal Constitucional Federal) ${ }^{22}$;

(b) a autorização à propositura do $\S 76$, Lei sobre o Tribunal Constitucional Federal, cobre-se somente com o número I e IV do artigo 103, CF. Deve ser notado que os outros autorizados à propositura assim possuem apenas uma autorização à propositura do tipo actio popularis, que se encontra no artigo 5 LXXIII, CF, como direito fundamental ${ }^{23}$. Segundo esse direito fundamental todo cidadão tem o poder para o emprego da ação popular com o objetivo de anulação de atuações para o dano do patrimônio público ou do patrimônio de corporações com participação estatal, da moral na administração, do meio ambiente e da herança histórica e cultural;

\footnotetext{
${ }^{22}$ A Lei sobre o Tribunal Constitucional Federal, assim como o título IX da Lei Fundamental, a Lei do Tribunal Constitucional Federal e a letra D, da Lei Constitucional Federal austríaca, foram traduzidas para o português. Vide HECK, Luís Afonso. Jurisdição constitucional e legislação pertinente no direito comparado. Porto Alegre: Livraria do Advogado, 2006. Vide Também HECK, Luís Afonso. op. cit., 2012, p. 265 et seq.

${ }^{23}$ Ver veto do artigo 2 II, da Lei número 9.882, de 3 de dezembro de 1999; semelhante BRASIL. Supremo Tribunal Federal. RTJ 215, p. 450. Dito de outro modo: no âmbito dos outros autorizados pode existir somente um interesse cívico. O interesse unido a um cargo obtido pelo voto popular, como é o caso no $§ 76$, da Lei sobre o Tribunal Constitucional Federal, portanto, não tem lugar. O sentido dessa união pode ser visto justamente no impulso inicial, até funcional, no plano da divisão de poderes (ou melhor, das funções), para a propositura. Também isso fala contra determinada jurisprudência do Supremo Tribunal Federal (ver, para ela, infra, nota de rodapé 31).
} 


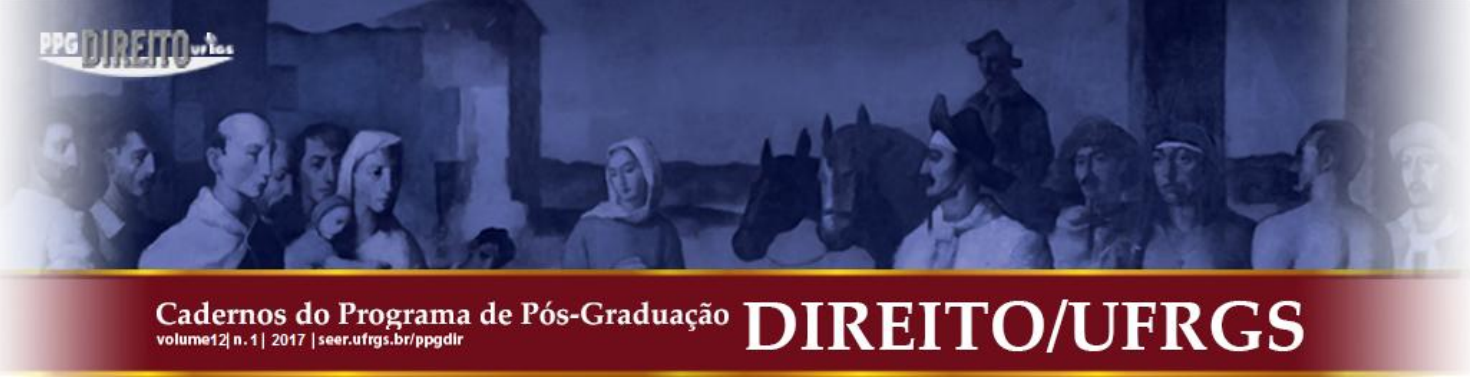

(c) o monopólio do exame e da rejeição de normas do artigo 102 §, CF, corresponde ao do Tribunal Constitucional Federal, § 78, Lei sobre o Tribunal Constitucional Federal;

(d) falta uma regulação correspondente ao $§ 79$, Lei sobre o Tribunal Constitucional Federal. O Supremo Tribunal Federal tenta vencer essa falta com a apresentação de Ipsen ao ele, por exemplo, trabalhar com a validez fática e normativa ${ }^{24}$;

(e) somente o Procurador-Geral da República (artigo 103 § 1, CF) e o Advogado-Geral da União (artigo $103 \S 3, \mathrm{CF}$ ) podem manifestar-se na ação de inconstitucionalidade; não podem isso, em compensação, a Câmara dos Deputados, Senado Federal, Governo Federal, assembleias e governos estaduais (comparar, em contrapartida, § 77, Lei sobre o Tribunal Constitucional Federal). O autor do ato impugnado não entra em jogo. Com isso o Supremo Tribunal Federal também não pode obter a visão de conjunto necessária sobre a situação fática e sua apreciação certamente não vai ao encontro do ajuste à coisa;

(f) a ação direta de constitucionalidade não existe no direito constitucional federal alemão;

(g) também a afirmação do não-cumprimento de uma prescrição fundamental não se encontra no direito constitucional federal alemão;

(h) por fim, a afirmação da omissão também não está prevista no direito constitucional federal alemão. Ela pode, porém, pelo $§ 493, \S 641$ e $\S 92$, Lei sobre o Tribunal Constitucional Federal, ser feita valer ${ }^{25}$.

\footnotetext{
${ }^{24}$ Em BRASIL. Supremo Tribunal Federal. RTJ 190, 1, p. 222, o livro "Rechtsfolgen der Verfassungswidrigkeit von Norm und Einzelakt" (1980) é expressamente citado e remetido à página 157, onde se trata de validez fática e normativa e da correlação entre ambas. Também em BRASIL. Supremo Tribunal Federal. RTJ 193, 3, p. 875 et seq., onde é indicada a página 266 e seguintes. Lá se fala da eliminação e conclusão de situações jurídicas inconstitucionais no plano da norma. O plano dos atos particulares e as formas de preclusão, que em BRASIL. Supremo Tribunal Federal. RTJ 193, 3, p. 875, também segundo Ipsen são mencionados, não se encontram, contudo, nele. Segundo Mendes, as fórmulas de preclusão do sistema jurídico brasileiro são usadas baseando-se em Zagrebelsky (MENDES, Gilmar Ferreira. Jurisdição constitucional. O controle abstrato de normas no Brasil e na Alemanha. São Paulo: Saraiva, 1996, p. 192 e a nota de rodapé na página 21). Isso é algo desconcertante, pois o escrito em BRASIL. Supremo Tribunal Federal. RTJ 193, 3, p. 875 et seq., 866, é do próprio Mendes. Crítico perante a ideia de Ipsen: HECKMANN, Dirk. Geltungskraft von Rechtsnormen. Tübingen: Mohr, 1997, S. 44 ff., 249 ff., 777 ff. Comparar com HECK, Luís Afonso. Jurisdição constitucional: teoria da nulidade versus teoria da nulificabilidade das leis. Porto Alegre: Livraria do Advogado, 2008, p. 53 e et seq.; HECK, Luís Afonso. Prefácio. In: PIÑEIRO, Eduardo Schenato. $O$ controle de constitucionalidade. Direito americano, alemão e brasileiro. Porto Alegre: Sergio Antonio Fabris, 2012, p. 15 et seq.

${ }^{25}$ Ver para isso, HECK, Luís Afonso. op. cit., 1994, p. 120 et seq., 123; HECK, Luís Afonso. op. cit., 2012, p. 141 et seq.
} 


\subsection{Controle de Normas Difuso}

Também em um controle de normas difuso, no qual, por motivo de um processo judicial de outro modo, também a inconstitucionalidade de uma lei é afirmada, pode o Supremo Tribunal Federal ser chamado pelo recurso extraordinário. Segundo o artigo 102 III, $\mathrm{CF}$, decide o supremo tribunal federal em assuntos, que foram decididos em única ou última instância, quando a decisão:

- contradiz uma prescrição da Constituição;

- declara a inconstitucionalidade de uma lei federal ou tratado;

- aprecia uma lei ou ato do governo legal como válido, que são impugnados perante a Constituição;

- aprecia uma lei local como válida, que é impugnada perante a lei federal.

Quando o Supremo Tribunal Federal, em decisão definitiva, qualifica a lei de inconstitucional, completamente ou em parte, então o Senado Federal é competente para a suspensão da efetivação (artigo $52 \mathrm{X}, \mathrm{CF}$ ). O Senado Federal, que se compõe de representantes dos estados e do Distrito Federal (artigo 46, CF), não revoga a lei. Essa competência não pode ao Senado Federal, porém, simplesmente ser negada com a referência à mutação constitucional ${ }^{26}$. Ao o Supremo Tribunal Federal fazer isso ${ }^{27}$, ele não guarda a

\footnotetext{
${ }^{26}$ Mendes apoia-se em uma manifestação de Bittencourt, que foi feita na época da Constituição Federal de 1946, cujo artigo 64 era semelhante ao artigo 52 X, CF 1988 (BITTENCOURT, C. A. Lúcio. O contrôle jurisdicional da constitucionalidade das leis. Rio de Janeiro: Forense, 1949, p. 145 et seq.), para mostrar a mutação constitucional (MENDES, Gilmar Ferreira. O papel do Senado Federal no controle federal de constitucionalidade. Um caso clássico de mutação constitucional. Revista de informação legislativa, Brasília, $\mathrm{n}$. 179, jul./set. 2008, p. 257 et seq.). Essa manifestação indica que a decisão do Senado Federal serve somente à dação de conhecimento, não é necessária, porém, para a extensão pessoal do efeito vinculativo. Ele mistura, com isso, o efeito da decisão do Supremo Tribunal Federal (nulidade, ex tunc) com o efeito vinculativo dessa decisão (inter partes), ao ele reconhecer o efeito erga omnes. O efeito erga omnes não se deixa, contudo, derivar da nulidade. Em conformidade com isso, Mendes diz, apesar disso, que a decisão do Senado Federal não é mais uma substancial (isto é, nenhuma anulação), mas somente uma formal (isto é, somente uma dação de conhecimento). Com isso, ele quer ver a mutação constitucional certificada (página 264, 269, 275). Dá na vista ainda que Mendes reduz a mutação constitucional em geral aos "fundamentos pragmáticos" do Supremo Tribunal Federal (página 274, 266), o que, por um lado, significa uma omissão legal e, por outro, mostra um conhecimento defeituoso da comparação de direito. Em geral, deixam, com isso, reconhecer-se antes estruturas que faltam. Não por último, na base desse modo de ver de Bittencourt e de Mendes está antes uma nulidade a priori, não uma nulidade jurídico-positiva, que pressupõe o direito natural. Para o direito natural, ver KELSEN, Hans. O fundamento da doutrina do direito natural. Tradução de Luís Afonso Heck. In: HECK, Luís Afonso (Org.). Direito natural, direito positivo, direito discursivo. Porto Alegre: Livraria do Advogado, 2010, p. 51 et seq.; KELSEN, Hans. Direito natural e direito positivo. Uma investigação de sua relação recíproca. Tradução de Waldir Alves. In: HECK, Luís Afonso (Org.). Direito natural, direito positivo, direito discursivo. Porto Alegre: Livraria do Advogado, 2010, p. 25 et seq..
} 


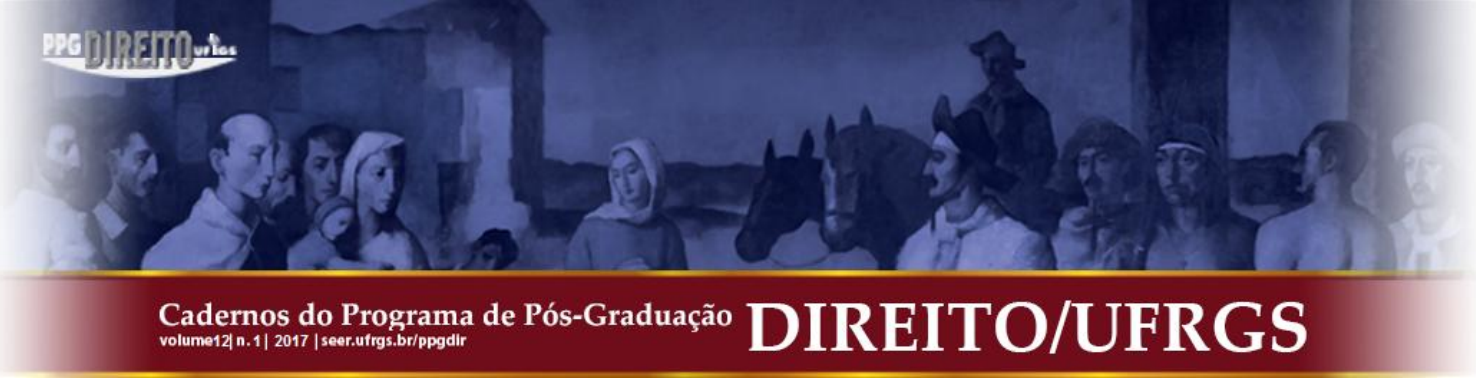

Constituição, mas viola ela. Pois, segundo o artigo $52 \mathrm{X}, \mathrm{CF}$, o Senado Federal tem a competência "exclusiva" para a interrupção, completa e em parte, da efetivação de leis que em virtude de decisão definitiva do Supremo Tribunal Federal foram qualificadas de inconstitucionais.

O recurso extraordinário serve à proteção objetiva da Constituição e das leis federais. Assim, ele serve também aos direitos subjetivos que com isso, cada vez, estão unidos.

\subsubsection{Autorizados à Propositura}

O recurso extraordinário é um meio de impugnação. Ele pode ser feito valer pelos participantes no procedimento respectivo (procedimento civil, penal, trabalhista, eleitoral). As particularidades estão reguladas nas leis (jurídico-ordinárias) respectivas.

\subsubsection{Monopólio do exame e da rejeição de normas}

No controle de normas difuso o Supremo Tribunal Federal não tem nem a competência de exame nem a competência de rejeição. Ambas estão nas mãos dos juízes federais. Nisso deve ser acentuado que a competência de rejeição não diz respeito à lei, mas ao efeito da decisão no caso particular. Assim, um juiz federal pode aceitar a objeção de inconstitucionalidade contra a lei X, o outro, não. Disso resultam um estilhaçamento constitucional e insegurança jurídica, a impossibilidade de produzir a unidade da Constituição e, assim, sua normatividade e o passar por alto do dador de leis pelo juiz particular ${ }^{28}$, pois para a parte processual a rejeição do efeito da lei no caso particular significa praticamente a rejeição da lei.

${ }^{27}$ BRASIL. Supremo Tribunal Federal. RTJ 200, 2, p. 839 et seq.; BRASIL. Supremo Tribunal Federal. RTJ 206, 2, p. 780 et seq.; BRASIL. Supremo Tribunal Federal. RTJ 208, 1, p. 170 et seq.; comparar com BRASIL. Supremo Tribunal Federal. RTJ 208, 2, p. 549; BRASIL. Supremo Tribunal Federal. RTJ 209, 3, p. 1266; BRASIL. Supremo Tribunal Federal. RTJ 217, p. 165; ver também BRASIL. Supremo Tribunal Federal. RTJ 205, 2, p. 930.

${ }^{28}$ Para isso, HECK, Luís Afonso. O controle normativo no direito constitucional brasileiro. Revista dos tribunais, São Paulo, v. 800, jul. 2002, p. 61, nota de rodapé 5 . 


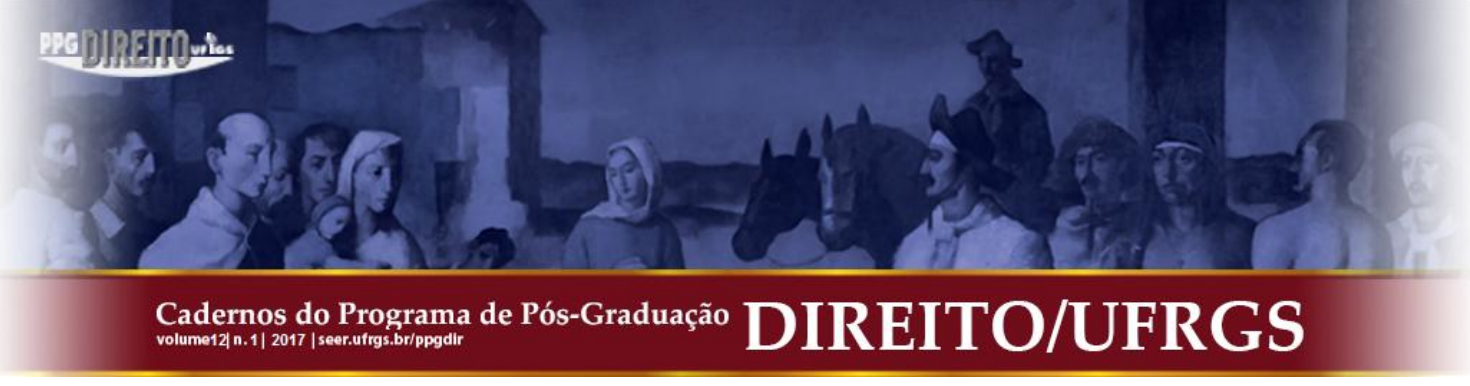

\subsubsection{Aspectos da Comparação de Direito}

Toma-se em consideração de novo o direito constitucional federal alemão, pode, então, ser comprovado:

(a) no Brasil não existe a apresentação judicial ( $\$ 80$, Lei sobre o Tribunal Constitucional Federal);

(b) o Supremo Tribunal Federal não tem o monopólio da rejeição como o Tribunal Constitucional Federal;

(c) esse faltar do monopólio da rejeição toma do Supremo Tribunal Federal, entre outras coisas, a possibilidade de desenvolvimento vinculativo conveniente dos princípios constitucionais, isto é, do princípio do Estado de Direito, do Estado Social, Democrático e do Estado Federal, assim como o Tribunal Constitucional Federal fez isso ${ }^{29}$;

(d) assim como o Tribunal Constitucional Federal guarda a Constituição pelo controle de normas concreto $^{30}$, assim também o Supremo Tribunal Federal guarda a Constituição no controle de normas difuso; em ambos os casos é um controle incidental. Com isso é malograda a jurisprudência do Supremo Tribunal Federal, à medida que ela dá ao controle de normas concentrado a preferência perante o difuso ${ }^{31}$;

(e) ao direito constitucional brasileiro a ideia da separação dos poderes no sentido de uma separação dos órgãos constitucionais ${ }^{32}$ é alheia ${ }^{33}$;

(f) no recurso extraordinário o demandante da apelação tem de apresentar a repercussão geral das questões jurídico-constitucionais que serão discutidas no caso (artigo $102 \S 3, \mathrm{CF})^{34}$. Na Alemanha isso é a tarefa dos tribunais ( 13 número 11, Lei sobre o Tribunal Constitucional

\footnotetext{
${ }^{29}$ Para isso, HECK, Luís Afonso. op. cit., 2012, p. 165 et seq.

${ }^{30}$ HESSE, Konrad. Elementos de direito constitucional da República Federal da Alemanha. Tradução de Luís Afonso Heck. Porto Alegre: Sergio Antonio Fabris, 1998, p. 498, número de margem 686.

${ }^{31}$ BRASIL. Supremo Tribunal Federal. RTJ 210, 1, p. 50 et seq.; BRASIL. Supremo Tribunal Federal. RTJ 218, p. 168 et seq.

${ }^{32}$ Ver MAURER, Hartmut. Staatsrecht I. 6. Auflage. München: Verlag C. H. Beck, 2010, S. 208, Rn. 12; 359, Rn. 1 ff.; 473, Rn. 1; 513, Rn. 1; 591, Rn. 1; 610, Rn. 1.

${ }^{33}$ Esse modo de ver falta. Com isso, o sentido organizatório da divisão de poderes também não existe. Ela é, antes, suposta quanto ao conteúdo, isto é, cada poder age para si, não com os outros.

${ }^{34}$ Ver para isso, BRASIL. Supremo Tribunal Federal. RTJ 202, 1, p. 396; BRASIL. Supremo Tribunal Federal. RTJ 205, 1, p. 60 e 468; BRASIL. Supremo Tribunal Federal. RTJ 206, 2, p. 922; BRASIL. Supremo Tribunal Federal. RTJ 206, 3, p. 1148; BRASIL. Supremo Tribunal Federal. RTJ 207, 1, p. 405; BRASIL. Supremo Tribunal Federal. RTJ 207, 3, p. 1245; BRASIL. Supremo Tribunal Federal. RTJ 208, 1, p. 372; BRASIL. Supremo Tribunal Federal. RTJ 208, 2, p. 859 e 871; BRASIL. Supremo Tribunal Federal. RTJ 209, 1, p. 430; BRASIL. Supremo Tribunal Federal. RTJ 209, 3, p. 1100; BRASIL. Supremo Tribunal Federal. RTJ 212, p. 600; BRASIL. Supremo Tribunal Federal. RTJ 220, p. 589, 602 e 606.
} 


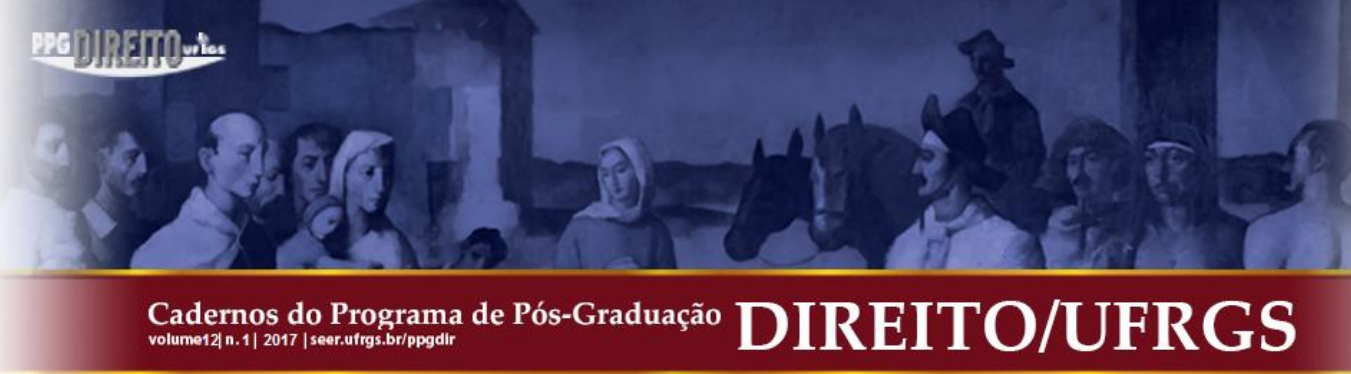

Federal). Seja notado ao lado que a repercussão geral brasileira quase somente é de utilidade para os grandes escritórios. Nisso, poderia o artigo $5 \mathrm{XXXV}, \mathrm{CF}$, que estabelece o acesso à justiça ${ }^{35}$, estar violado. $\mathrm{O}$ artigo $5 \mathrm{XXXV}, \mathrm{CF}$, determina que por lei nenhuma violação ou perigo ao direito deve ser excluído da revisão pelo poder jurisdicional.

\section{VINCULAÇÃO DA DECISÃO}

Para a vinculação das decisões do Supremo Tribunal Federal deve no controle de normas ser diferenciado. Isso resulta do fato que o tribunal não possui o monopólio da rejeição.

\subsection{No Controle de Normas Concentrado}

Aqui as decisões do Supremo Tribunal Federal têm efeito vinculativo. Uma vez, intra omnes (contra todos) e, outra vez, erga omnes (contra os órgãos do poder judicial e da administração pública direta e indireta ${ }^{36}$, na federação, estados e no plano do município) (artigo 102 § 2, CF; artigo 28, parágrafo único, Lei número 9.868, de 10 de novembro de 1999). A decisão da afirmação do não-cumprimento de uma prescrição fundamental (artigo $102 \S 1, \mathrm{CF}$ ) vincula também a todos, inclusive todos os órgãos do poder público (artigo $10 \S$ 3, Lei número 9.882, de 3 de dezembro de 1999). Na perspectiva da comparação de direito, isto corresponde ao $\S 312$ II, Lei sobre o Tribunal Constitucional Federal, e aquilo ao $\S 31$ I, Lei sobre o Tribunal Constitucional Federal.

Não é visível por que a decisão judicial sobre a prescrição fundamental vincula o dador de leis e a sobre constitucionalidade, inconstitucionalidade e omissão não. Contrapõe-se isso à chamada mutação constitucional, então isso é ainda mais desconcertante, pois, por um lado, o Supremo Tribunal Federal quer intervir nas competências do dador de leis e, por outro, deixar livre legislativamente do efeito vinculativo das normas constitucionais. Cabe ao dador de leis ocupar-se com isso de novo para obter uma solução jurídico-constitucionalmente conveniente.

\footnotetext{
${ }^{35}$ Algo semelhante está previsto em ALEMANHA. Lei Fundamental, de 08 de maio de 1949. Artigo 19 IV.

${ }^{36}$ Essa terminologia remonta ao descrito em BRASIL. Decreto-Lei 200, de 25 de fevereiro de 1967. Artigos 4 I e 4 II com Artigo 5 I-IV.
}

Cadernos do Programa de Pós-Graduação em Direito PPGDir./UFRGS | Edição Digital | Porto Alegre | Volume XII | Número 1 | 2017 | P.166 - 187 


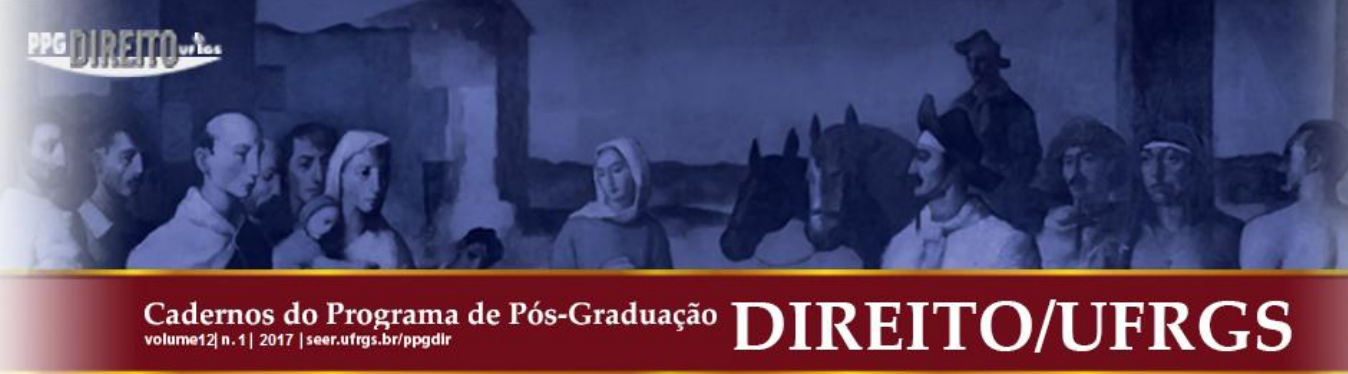

Ainda deve ser mencionado que na comprovação da inconstitucionalidade da omissão é dado conhecimento ao poder competente para tomar as medidas necessárias. Está a omissão em um órgão da administração, então ele tem de tomar essas em trinta dias (artigo $103 \S 2$, $\mathrm{CF})$.

Com a representação pode o Procurador-Geral da República provocar uma decisão do Supremo Tribunal Federal. Caso a infração contra princípios constitucionais seja certificada na decisão, então serve essa decisão como fundamento de uma intervenção da federação no estado afetado ou no Distrito Federal afetado (artigo 36 III, CF).

\subsection{No controle de Normas Difuso}

Se o Supremo Tribunal Federal, por uma decisão definitiva, qualifica a lei de inconstitucional $^{37}$, então isso vale somente inter partes, isto é, somente para as partes processuais. Somente depois da suspensão da efetivação dessa lei ou de uma parte dessa lei pelo Senado Federal ${ }^{38}$ cabe a essa efeito erga omnes. Isso depreende-se do artigo $52 \mathrm{X}, \mathrm{CF}$, acima citado. Se se olha mais rigorosamente, então o juiz federal particular faz exatamente aquilo que o Senado Federal faz: ele também suspende a efetivação da lei, embora os manuais, um pouco desconcertante, falem da declaração de inconstitucionalidade da lei.

\section{NULIDADE OU NULIFICABILIDADE ${ }^{39}$}

Pela Lei número 9.868, de 10 de novembro de 1999, artigo 27, e Lei número 9.882, de 3 de dezembro de 1999, artigo 11, foi introduzida a nulificabilidade ${ }^{40}$, posteriormente também pela Lei número 11.417 , de 19 de dezembro de 2006, artigo 3 XI $\S 4$. Nulificabilidade significa que a decisão do tribunal é constitutiva e, em regra, atua ex nunc. Ela distingue-se da nulidade pelo fato de a decisão do tribunal sobre a nulidade ser declaratória e atuar sempre ex tunc. A nulificação vale, assim, no âmbito do controle de normas concentrado. O Supremo Tribunal Federal tentou aplicar ela também no controle de normas difuso, onde vale a

\footnotetext{
${ }^{37}$ O dispositivo da decisão do tribunal deixa apresentar-se assim: “(...) qualifica a lei (uma determinada parte da lei) de inconstitucional".

${ }^{38}$ As decisões do Senado Federal, que efetuam isso, encontram-se em PIÑEIRO, Eduardo Schenato. $O$ controle de constitucionalidade. Direito americano, alemão e brasileiro. Porto Alegre: Sergio Antonio Fabris, 2012, p. 255 et seq.

${ }^{39}$ Pormenorizado para isso, HECK, Luís Afonso. Jurisdição constitucional: teoria da nulidade versus teoria da nulificabilidade das leis. Porto Alegre: Livraria do Advogado, 2008.

${ }^{40}$ Para isso, KELSEN, Hans. op. cit., 1929, S. $43 \mathrm{ff}$.
} 
nulidade, e apoia-se no Corpus Juris Secundum e na nulificabilidade no sentido de Kelsen ${ }^{41}$. Posteriormente o Supremo Tribunal Federal retoma essas ideias de novo e apoia-se agora no sistema de controle de normas dos Estados Unidos da América ${ }^{42}$ e fala de modulação da decisão ${ }^{43}$. Nessa época, a teoria da nulificabilidade, isto é, a teoria da não-retroatividade, segundo a qual a decisão da Suprema Corte atua ex nunc ou é prospectiva, já estava abandonada nos Estados Unidos da América ${ }^{44}$. A diferença entre nulidade e nulificabilidade parece não ser clara ao Supremo Tribunal Federal ${ }^{45}$.

Como Piñeiro ${ }^{46}$ com razão acentua, trata-se nos Estados Unidos da América, primeiro, não da modulação do efeito da inconstitucionalidade, mas da fixação do precedente ao caso concreto, assim como, segundo, da relação Constituição-caso do precedente. Mais além, poderia, em virtude do artigo 27 (Lei número 9.868, de 10 de novembro de 1999) cada juiz federal fazer a chamada modulação. Não existe fundamento jurídico para limitar ela ao Supremo Tribunal Federal ${ }^{47}$.

\section{CONSIDERAÇÕES FINAIS}

Pode, segundo o apresentado, de lege ferenda, ser proposto que deveria ser aceito um modelo conjugado. E isso seria um controle de normas abstrato e concreto com apoio na situação jurídica na Alemanha. Sob conjugado eu entendo aqui a união do controle de normas concentrado e difuso neste sentido, que ao Supremo Tribunal Federal seja confiado o monopólio de rejeição. Uma tal união iria então parecer-se ao controle de normas alemão. As vantagens são que, com isso, por um lado, deixa-se o controle de exame nos juízes e, assim, não se passa por alto da tradição constitucional brasileira do controle de normas difuso; por

\footnotetext{
${ }^{41}$ BRASIL. Supremo Tribunal Federal. RTJ 82, 3, p. 795. Isso foi no ano de 1977, sob a validez da Constituição Federal de 1969.

${ }^{42}$ Vide BRASIL. Supremo Tribunal Federal. RTJ 197, 2, p. 708 et seq.; BRASIL. Supremo Tribunal Federal. RTJ 200, 2, p. 843 et seq.; BRASIL. Supremo Tribunal Federal. RTJ 208, 1, p. 175.

${ }^{43}$ BRASIL. Supremo Tribunal Federal. RTJ 201, 2, p. 765; BRASIL. Supremo Tribunal Federal. RTJ 203, 3, p. 1237 et seq., p. 1334 et seq.; BRASIL. Supremo Tribunal Federal. RTJ 217, p. 545 et seq. e BRASIL. Supremo Tribunal Federal. RTJ 205, 2, p. 901. Na base da modulação-(decisão) está a nulificabilidade, isto é, a decisão do poder judicial tem caráter constitutivo e pode atuar ex tunc ou ex nunc.

${ }^{44}$ Para isso, STEPHENS, Pamela J. A nova doutrina da retroatividade. Igualdade, confiança e stare decisis. Tradução de Pablo Giordano Bernardi Bombardelli. Revisão de tradução por Luís Afonso Heck. Porto Alegre: Sergio Antonio Fabris, 2012.

${ }^{45}$ Comparar BRASIL. Supremo Tribunal Federal. RTJ 205, 2, p. 905; BRASIL. Supremo Tribunal Federal. RTJ 2216, p. 522 et seq.; BRASIL. Supremo Tribunal Federal. RTJ 217, p. 53 et seq., 60 e 238 et seq..

${ }^{46}$ PIÑEIRO, Eduardo Schenato. op. cit., p. 229.

${ }^{47}$ Comparar com PIÑEIRO, Eduardo Schenato. op. cit., p. 232.
} 


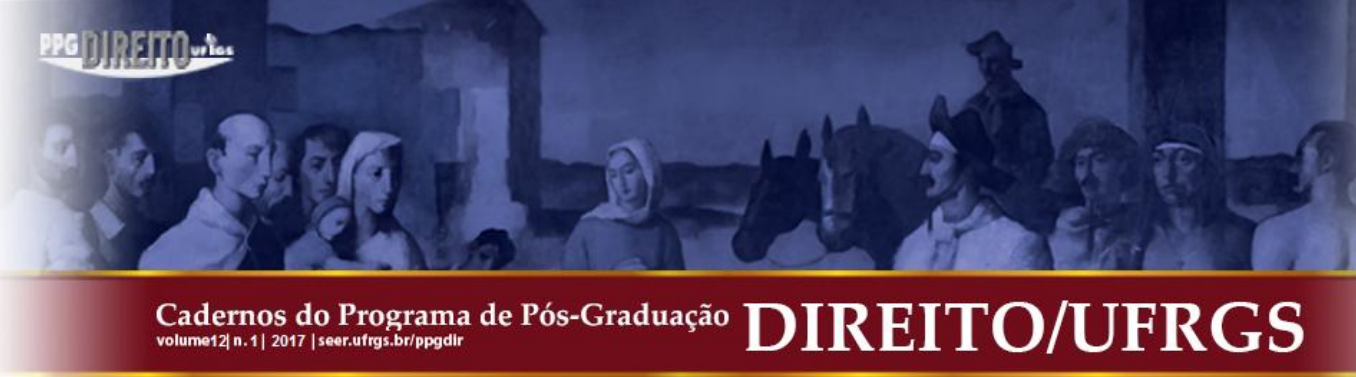

outro, que a concentração da rejeição de normas no Supremo Tribunal Federal irá trazer consigo uma "arrumação jurídico-procedimental"; e, por último, ambos irão exigir também uma tomada de posição para com a proteção jurídico-procedimental subjetiva dos direitos fundamentais no Supremo Tribunal Federal por um recurso jurídico idôneo. Isso também vai ao encontro do Supremo Tribunal Federal, pois quando ele é da opinião que o dever de cada tribunal constitucional é o asseguramento da eficácia dos direitos fundamentais e da ordem constitucional como um todo e acredita que isso é o seu papel principal como guarda da Constituição ${ }^{48}$, então ele tem de, para isso, também ser dotado com os meios de procedimento idôneos por lei.

\section{REFERÊNCIAS}

ALEMANHA. Lei Fundamental, de 08 de maio de 1949.

BITTENCOURT, C. A. Lúcio. O contrôle jurisdicional da constitucionalidade das leis. Rio 183 de Janeiro: Forense, 1949.

BRASIL. Constituição da República Federal do Brasil, de 05 de outubro de 1988. Código de Processo Penal. Decreto-Lei 3.689, de 3 de outubro de 1941.

. Decreto-Lei 200, de 25 de fevereiro de 1967.

. Supremo Tribunal Federal. Habeas Corpus 82959.

. Lei 9.507, de 12 de novembro de 1997.

. Lei 12.016, de 7 de agosto de 2009

. Supremo Tribunal Federal. Recurso Extraordinário 197917.

. Supremo Tribunal Federal. RTJ 82, 3.

. Supremo Tribunal Federal. RTJ 190, 1.

. Supremo Tribunal Federal. RTJ 193, 3.

. Supremo Tribunal Federal. RTJ 194, 2.

${ }^{48}$ BRASIL. Supremo Tribunal Federal. RTJ 215, p. 451. 
. Supremo Tribunal Federal. RTJ 197, 2.

. Supremo Tribunal Federal. RTJ 199, 3.

. Supremo Tribunal Federal. RTJ 200, 2.

. Supremo Tribunal Federal. RTJ 201, 2.

. Supremo Tribunal Federal. RTJ 202, 1.

. Supremo Tribunal Federal. RTJ 203, 3.

. Supremo Tribunal Federal. RTJ 205, 1.

. Supremo Tribunal Federal. RTJ 205, 2.

. Supremo Tribunal Federal. RTJ 206, 2.

. Supremo Tribunal Federal. RTJ 206, 3.

. Supremo Tribunal Federal. RTJ 207, 1.

. Supremo Tribunal Federal. RTJ 207, 3.

. Supremo Tribunal Federal. RTJ 208, 1.

. Supremo Tribunal Federal. RTJ 208, 2.

. Supremo Tribunal Federal. RTJ 209, 1.

. Supremo Tribunal Federal. RTJ 209, 3.

. Supremo Tribunal Federal. RTJ 210, 1.

. Supremo Tribunal Federal. RTJ 210, 3.

. Supremo Tribunal Federal. RTJ 211.

. Supremo Tribunal Federal. RTJ 212.

. Supremo Tribunal Federal. RTJ 213.

. Supremo Tribunal Federal. RTJ 215.

. Supremo Tribunal Federal. RTJ 216.

. Supremo Tribunal Federal. RTJ 217. 
. Supremo Tribunal Federal. RTJ 218.

. Supremo Tribunal Federal. RTJ 220.

Supremo Tribunal Federal. RTJ 2216.

GADAMER, Hans-Georg. Wahrheit und Methode 1. Grundzüge einer philosophischen Hermeneutik. 6. Auflage. Tübingen: Mohr, 1990.

HECK, Luís Afonso. Jurisdição constitucional: teoria da nulidade versus teoria da nulificabilidade das leis. Porto Alegre: Livraria do Advogado, 2008.

. Jurisdição constitucional e legislação pertinente no direito comparado. Porto Alegre: Livraria do Advogado, 2006.

O controle normativo no direito constitucional brasileiro. Revista dos tribunais, São Paulo, v. 800, jul. 2002.

O recurso constitucional na sistemática jurídico-constitucional alemã. Revista de informação legislativa, Brasília, n. 124, out./dez., 1994.

O tribunal constitucional federal e o desenvolvimento dos princípios constitucionais. Contributo para uma compreensão da jurisdição constitucional federal alemã. 2. ed. Porto Alegre: Sergio Antonio Fabris, 2012.

Prefácio. In: PIÑEIRO, Eduardo Schenato. O controle de constitucionalidade. Direito americano, alemão e brasileiro. Porto Alegre: Sergio Antonio Fabris, 2012.

HECKMANN, Dirk. Geltungskraft von Rechtsnormen. Tübingen: Mohr, 1997.

HESSE, Konrad. Elementos de direito constitucional da República Federal da Alemanha. Tradução de Luís Afonso Heck. Porto Alegre: Sergio Antonio Fabris, 1998.

KELSEN, Hans. Direito natural e direito positivo. Uma investigação de sua relação recíproca. Tradução de Waldir Alves. In: HECK, Luís Afonso (Org.). Direito natural, direito positivo, direito discursivo. Porto Alegre: Livraria do Advogado, 2010.

. O fundamento da doutrina do direito natural. Tradução de Luís Afonso Heck. In: HECK, Luís Afonso (Org.). Direito natural, direito positivo, direito discursivo. Porto Alegre: Livraria do Advogado, 2010.

Wesen und Entwicklung der Staatsgerichtsbarkeit. VVDStRL, n. 5, 1929.

MAURER, Hartmut. Jurisdição constitucional. In: MAURER, Hartmut. Contributos para o direito do estado. Tradução de Luís Afonso Heck. Porto Alegre: Livraria do Advogado, 2007. 


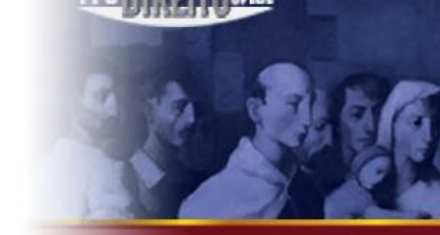

Cadernos do Programa de Pós-Graduação volume12/ n.1| 2017 | seer.ufrgs.br/ppgdilr

\section{DIREITO/UFRGS}

Staatsrecht I. 6. Auflage. München: Verlag C. H. Beck, 2010.

MENDES, Gilmar Ferreira. Jurisdição constitucional. O controle abstrato de normas no Brasil e na Alemanha. São Paulo: Saraiva, 1996.

O papel do Senado Federal no controle federal de constitucionalidade. Um caso clássico de mutação constitucional. Revista de informação legislativa, Brasília, n. 179, jul./set. 2008.

PIÑEIRO, Eduardo Schenato. O controle de constitucionalidade. Direito americano, alemão e brasileiro. Porto Alegre: Sergio Antonio Fabris, 2012.

STEPHENS, Pamela J. A nova doutrina da retroatividade. Igualdade, confiança e stare decisis. Tradução de Pablo Giordano Bernardi Bombardelli. Revisão de tradução por Luís Afonso Heck. Porto Alegre: Sergio Antonio Fabris, 2012.

TAVARES, André Ramos; ROTHENBURG, Walter Claudius (Org.). Argüição de descumprimento de preceito fundamental: análises à luz da lei n. 9.882/99. São Paulo: Atlas, 2001.

Submissão: 08/04/2017

Aceito para Publicação: 13/07/2017 


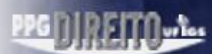

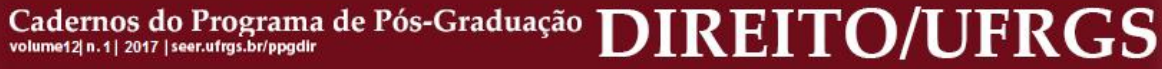

